\title{
Trade unions and worker movements in the North American communications industries
}

\author{
Vincent Mosco \\ Vincent Mosco is Canada Research Chair and Professor of \\ Sociology at Queen's University in Kingston, Ontario, Canada.
}

\begin{abstract}
This paper reports on a project that examines trends in North American labour movements, and specifically in the workforce, in the converging communications, culture, and information technology sectors. Drawing on documentary evidence and interviews, the paper concentrates on two important developments: efforts to unify workers across the knowledge and communication industries, and the rise of worker movements that operate in conjunction with, but outside, the formal trade union structure. The paper begins by situating these developments within debates about labour in a 'post-industrial', 'information', or 'network' society. It describes the challenges facing workers in the knowledge sector, especially rapid technological change, massive corporate consolidation, the rise of the neo-liberal state and divisions between cultural and technical workers in the knowledge sector. The paper proceeds to describe how North American workers are responding within the traditional trade union system, primarily through forms of consolidation or trade union convergence (such as the Communication Workers of America), and also through worker movements operating outside the traditional trade union system in the information technology and cultural sectors (for example WashTech and the National Writers Union). The paper concludes by addressing the significance of these developments. Do they portend a rebirth of North American labour activism or do they represent its last gasps?
\end{abstract}

\section{Introduction}

Research from a variety of perspectives has demonstrated the importance of information and communication labour in the modern economy (Dyer-Witheford, 1999; Huws, 2003; Terranova, 2004). In an era characterised by declining trade union participation, increasing corporate concentration, and the rise of global conglomerates that feed into - and are fed by - the spread of new communication and information technology, North American knowledge workers have begun to explore new ways to increase the power of labour. This is especially the case in the communications sector, which provides the equipment that makes globalisation possible, and in the production and distribution of the ideas that make it work.

One approach is to pursue trade union mergers, a strategy designed to restructure labour unions along much the same lines as the corporations that employ their members. There is considerable research on the value of mergers or convergence 
among trade unions, including in the communication and information industries (Batstone, 1984; Katz, 1997; Stone, 2004). Convergent unions like the Communications Workers of America (CWA) or the Communications, Energy and Paperworkers Union of Canada (CEP) bring together workers in what were once independent industries - newspapers, telecommunications, sound recording and broadcasting - but which are now part of cross-media conglomerates. These unions also recognise that it is not just the boundaries between employers that have become blurred; the boundaries between what were once distinct forms of work have also been obscured through the spread of digital technology. Labour convergence, therefore, is seen as an appropriate response to technological and corporate convergence (McKercher, 2002; Swift, 2003; Bahr, 1998).

A second approach is to create non-traditional worker organisations, which draw people into the labour movement who cannot or will not join a traditional trade union. Such groups provide a range of services and support for workers, their families and their communities but do not engage in collective bargaining. In North America, they are particularly prominent in the high-technology area (Stone, 2004; Kline, DyerWitheford \& de Peuter, 2003; van Jaarsveld, 2004).

\section{Theorising knowledge labour}

Call centre employees, university professors, and journalists have very little in common but they do share important roles in the knowledge industries. Analysis and debate about this sector began in earnest shortly after World War II when scholars began to notice growth in the number of jobs outside the manufacturing sector. In the early years, the academic emphasis was on developing measures to track the growth of the information sector as an economic force. Machlup (1962) was among the leaders in charting the expansion of the data and information components of the economy. Porat (1977) later built on this work to document the shift from an economy based on the agriculture (primary) and manufacturing (secondary) sectors to one rooted in services (tertiary) and information (quaternary) occupations. However, neither Machlup nor Porat addressed the political, social, and cultural implications of this transformation with anything approaching the theoretical sophistication of Daniel Bell (1973).

According to Bell, we were not merely experiencing a growth in data and information, nor merely a shift in the major occupational categories, but a transformation in the nature of capitalist society. Capitalism had been governed for two centuries by industrialists and their financiers who comprised the capitalist class. Now, with the rise of a society dependent on technology, and particularly on the production and distribution of information, Bell maintained that a new class of leaders, a genuine knowledge class of well-trained scientific-technical workers was rising to prominence and ultimately to leadership of a post-industrial capitalism. Inherited wealth and power would shrink in significance and a genuine meritocracy would rule. Such a society would not necessarily be more democratic, but it did portend a shift in power from its traditional base in family inheritance to technical and scientific knowledge. The ranks of knowledge workers would literally power and manage this new postindustrial economy, leading to steady economic growth and the decline of historic ideologies. According to Bell, political battles over public policy would diminish as 
technical algorithms and knowledge-based measures, would govern. No doubt, tensions would exist in such a society, but these would be technical and not ideological. The only potential for serious division lay outside the economic and political spheres and resided in, as Bell (1976) would argue in his next, far darker, book, the cultural sphere. The only significant internal threat to this post-industrial society was a culture sinking deeper into consumer hedonism and irrational beliefs. The conjunction of two apparent opposites, materialism and the counter-culture, threatened the foundations of post-industrialism because they challenged the delayed gratification and support for technical rationality that were required to maintain it.

It did not take long for others to conclude that, cultural issues aside, postindustrialism itself was not inherently progressive. For Herbert Schiller (1973), postindustrialism meant the rise of transnational media and communication businesses that would pump out support for American values, including its military and imperial ambitions, and eliminate alternatives through increasingly concentrated market power. According to Harry Braverman (1973), for the vast majority of workers in the service, retail, and knowledge professions, labour would be as regimented, and ultimately deskilled, as it had been in assembly-line manufacturing. Indeed, given the immateriality of knowledge work, it would be easier than in the industrial era to separate conception from execution and to concentrate the power of conception (eg design and management) in a dominant class.

There has been widespread debate ever since Bell, Braverman, and Schiller addressed these issues in 1973, but there is some agreement in key areas. For instance, there is consensus that a shift from manufacturing to knowledge work has already occurred in more developed economies and is beginning in some less developed ones. Yes, people agree that there was and still is considerable knowledge required in much of manufacturing as well as in agricultural work. But the difference today is that an increasing amount of work is taken up with the production and distribution of information, communication, and knowledge. Furthermore, there is agreement that a dynamic process of deskilling, upskilling and reskilling is taking place in the occupational hierarchy. At different times and in different sectors one or another of these processes predominates, but the labour process, most concur, cannot be reduced to the singularity of a single process (Barley \& Kunda, 2004; Brint, 2001; Powell \& Snellman, 2004). Nevertheless, there is also agreement that companies have benefited from reducing the skill component of jobs or eliminating jobs entirely and replacing them with automated systems. This especially applies to jobs traditionally filled by women (Huws, 2003).

Where deskilling or job elimination is not possible, companies have accomplished the same objective by moving jobs to low wage areas within a country or shipping them abroad. Since knowledge work typically does not require movement of material things over long distances (for example, call centres and software engineering contain little or no bulk), the production process requires the use of global telecommunications systems, the costs of which have been declining over years of technological development. This process of outsourcing enables, for example, an American company to use data entry workers in China, call centre employees in Canada, and software 
programmers in India, while incurring a fraction of the labour costs it would encounter by employing workers in the United States. This process is, by and large, an extension of the general predominance of a business-led neo-liberal agenda that has transformed the business-labour social contract of the 1950s and 1960s (guaranteed jobs at a living wage with a package of benefits) to a business-first agenda that, in the name of productivity, has made jobs, wages, and certainly benefits, far from a guarantee in today's more developed economies. Because outsourcing is part of this wider business agenda, which has also attacked the social policy instruments that protected labour and trade unions, it has been all the more difficult for working people to mount a successful defence (Economic Policy Institute, 2004).

Nevertheless, outsourcing is not without its antimonies. A large share of outsourcing in the knowledge and communication sectors is contained within the developed world where, for example, Canada has become Hollywood North and Ireland continues to benefit from its skilled English-speaking workforce and wage and tax premiums. Moreover, although India is a major source of low wage knowledge labour, its major companies, such as ICICI, Tata, Infosys, and Wipro, are taking a leading role in the outsourcing industry. Their activities in North America suggest that place still matters and that culture still counts. Finally, resistance is growing from labour organisations and that is one reason why the expansion of convergent unions and worker associations in the knowledge and communication sectors is particularly important (Elmer \& Gasher, 2005; Mosco, 2006). However, the data on general trade union membership in North America are not encouraging for those who would like to see this resistance expand.

\section{The crisis in North American trade unionism}

Trade union membership rates have steadily declined from a high of $20.1 \%$ in 1983, the first year for which comparable union data are available. In 2005, $12.5 \%$ of wage and salary workers in the US were trade union members. According to the US Bureau of Labour Statistics, this was down from $12.9 \%$ in 2003 and $12.7 \%$ in 2004 . The figures for private sector members are even lower, about $7.8 \%$, compared to $36.5 \%$ of government workers. Two occupational groups - education, training, and library occupations, on the one hand, and protective service occupations on the other - had the highest unionisation rates in 2004, at about 38.5 and $37 \%$ respectively. The first of these two groups of workers is centrally located in the knowledge industry and demonstrates the potential for union growth in this rapidly expanding sector (US Bureau of Labour Statistics, 2006). Unionisation is marginally higher in Canada where, in 2005, 30.7 $\%$ of workers were union members, an increase from $30.4 \%$ in 2004 (Bédard, 2005). According to a 2004 government report, $72 \%$ of Canadian public sector workers and $18 \%$ of employees in the private sector were union members. However, union density is also down in Canada from the $35 \%$ of workers who were union members in 1990 (Statistics Canada, 2004).

Admittedly, these numbers should be placed in their historical context because while union density rates were at similarly low levels in the 1920s, they bounced to high levels in the 1930s that were maintained through the early 1950s. As late as 1932, an 
eminent American labour economist speaking to a meeting of the American Economics Association, reflected on the American Federation of Labour's loss of $40 \%$ of its members and pronounced that technological change made it nearly impossible for the union movement to regain its earlier strength (Clawson, 2003). Furthermore, although union density is declining, the absolute number of union members is growing with an overall expansion of the workforce in both the United States and Canada. While it is the case that both countries have more unionised workers than ever before, density rates continue to decline and there is general agreement among scholars and trade unionists themselves that workers in the knowledge economy face serious problems. One strategy that stands out as attempting to rectify this problem is the merger strategy that has been adopted by established trade unions in the United States and Canada to better mobilise and concentrate resources. This has been especially evident in the knowledge and communication sectors. In order to understand this strategy as it applies to the knowledge and media sector, it is useful to consider the concept of convergence.

\section{The concept of convergence}

Convergence is one of the central developments taking place across the media, telecommunications and information sectors of the communications industry. Generally speaking, it refers to the integration of technologies, arenas and institutions in these industries and more specifically to the integration of the devices that these industries use and the information they process, distribute and exchange over and through these devices (Babe, 1996; McKercher, 2002; Winseck, 1998). By integrating computers and telecommunications, the internet is now an iconic example of technological convergence.

This form of convergence is also linked to, and partly responsible for, the convergence of once separate industries into a common arena providing electronic information and communication services. Differences in the social relations of technology, including corporate and regulatory arrangements negotiated in the 19th and 20th Centuries that divided up the media into fields of mutually exclusive dominance, once erected thick walls between print media, electronic media, telecommunications, and information services and between labour processes and trade union structures in those industries. Now, owing largely to the power of private communication companies, the weakening enthusiasm of governments to support public service communication, and the decline in social movements committed to public service communication, these walls are breaking down, eliminating many of the distinctive features that divided these separate industries and creating one large electronic information and communication services arena.

Convergence has enabled the interconnection of technologies to create new systems of hardware and new levels of service, such as wireless networking in Wi-Fi and WiMax systems. Hardware convergence has been greatly advanced with the development of a common digital language that does not distinguish between audio, video or data transmission; reducing all communication to one language that provides a manifold increase in the quantity and quality of electronic communication. Digitisation has the technological advantage of providing enormous gains in transmission speed and 
flexibility over earlier forms of electronic communication, which were largely reliant on analogue techniques (Longstaff, 2002). But digitisation takes place in the context of, and greatly expands, the process of commodification, or the transformation of what amounts to a resource into a marketable product or service. On the one hand, the expansion of the commodity form provides the context for who leads the process of digitisation and how it is applied. On the other hand, digitisation is used to expand the commodification of information and entertainment, specifically to enlarge markets for communication products, deepen the commodification of labour involved in the production, distribution and exchange of communication, and expand markets in the audiences that receive and make use of electronic communication (Mosco, 1996).

Companies are taking advantage of technological convergence by creating corporate or institutional convergence. This is embodied in the scope of merger and acquisition activity that is most prominent within the knowledge and media industries, though not limited to these sectors (Mosco, 2004; Nichols \& McChesney, 2005; Schiller, 1999). Convergence is bringing together communication firms which want to take advantage of opportunities to integrate products and services, to cross-promote and cross-market products and services in previously separate spheres like entertainment and news, and to cross-produce content for a range of media. Corporate convergence does not, in and of itself, guarantee success. In the short run, it sometimes does not produce the synergies that companies anticipate, such as the integration of the cultures of the print newsroom and the broadcasting station. It also sometimes results in content that cannot attract audiences. These facts help to explain the difficulties experienced by convergent media firms like AT\&T, Bell Canada Enterprises and AOL Time Warner. Indeed, according to the Wall Street Journal, Time Warner executives no longer talk about 'synergies' but about 'adjacencies' (Karnitschnig, 2006). Moreover, digitisation itself is not a flawless process and technical problems do slow its development.

Another stumbling block in the process of technological and institutional convergence is the state of government regulation. Technological and institutional convergence has raised fundamental problems for regulatory policies that were established for discrete industries based on discrete technologies. But these may be short-term problems, which can result in cyclical declines over the course of a secular trend, rather than as evidence that convergence has failed. Large units enable businesses to better control their environments, limiting competitive pressures even as they benefit by developing internal market competition among divisions.

Convergence is not just a technological, political and organisational process. It is also a myth or a story about how computer communication is revolutionising technology, politics and society. As such, it is part of a sublime vision that, in its strongest form, envisions the technology creating the conditions for the end of history, the end of geography, and the end of politics (Mosco, 2004). Convergence is therefore more than just a term to describe an ostensible change in technology and organisation. It is part of a utopian discourse that aims to lead us from the coarse materiality of, in Nicholas Negroponte's terms, 'the world of atoms', so that we can 'learn to be digital' (Negroponte, 1996). This affirmative vision is used to rationalise deepening social inequalities, tightening surveillance practices, and the growing control of a handful of 
companies over the production and distribution of communication and information. To say that convergence is a myth is not to imply that it is false. Rather, myths take a basic empirical reality and enlarge it by attributing transformative social and cultural consequences that are not currently justified by empirical evidence. Convergence, as both a political and cultural process, creates considerable pessimism among those who support public service communication, diversity in the form and content of knowledge, information and entertainment, and universal and equitable access to media (Artz \& Kamalipour, 2003; Herman \& Chomsky, 2002; Winter, 2005). But the growth of trade union convergence is creating some grounds for optimism.

\section{Trade union convergence}

In the United States, a range of media unions - the International Typographical Workers Union (ITU), the Newspaper Guild, and the National Association of Broadcast Employees and Technicians (NABET) - have joined the Communications Workers of America (CWA). The model of a convergent union (or, as the CWA likes to call itself, 'a trade union for the information age'), the CWA represents workers employed in telecommunications, broadcasting, cable TV, newspaper and wire service journalism, publishing, electronics and general manufacturing, as well as airline customer service, government service, health care, education and other fields. Among the major employers of CWA members are AT\&T, GTE, the Regional Bell telephone companies, Lucent Technologies/Bell Labs, the NBC and ABC television networks, the Canadian Broadcasting Corporation (CBC), and major newspapers such as the New York Times, the Wall Street Journal and the Washington Post.

In Canada, the Communications, Energy and Paperworkers Union (CEP) has pursued a similar pattern. It has merged with many of the Canadian units from the ITU, the Newspaper Guild and Canadian NABET. Its members work in pulp and paper mills, telephone companies, newspapers, radio and television. They are also employed as graphic artists, hotel workers, computer programmers, truck drivers and nurses. Furthermore, the Telecommunications Workers Union (TWU), which historically represented telephone workers in British Columbia, was able to extend its jurisdiction over telecommunications workers in other parts of the country because the Canadian labour regulatory body, the CIRB, determined that technological and industry convergence was best represented by a single converged union.

To a degree, the unions see these actions as defensive, or as ways of protecting their members. But significantly, they also see labour convergence as an attempt to take advantage of synergies brought about by a growing convergence in the nature of their work (Bahr, 1998). Since these unions represent workers who are increasingly involved in producing for a converging electronic information services arena, they see improved opportunities for organising and bargaining. In essence, converging technologies and converging companies have led workers to come together across the knowledge industry (McKercher, 2002).

This strategy has not always been successful. For example, one of the keys to mobilising against the increasingly integrated video and film industries, encompassing mainly television and Hollywood, is to merge unions representing both sectors, just 
as companies like Disney and Fox have used their merged power to control their respective workers. Without a unified workforce, these companies can dictate the terms of contracts outlining the conditions under which revenues from multiple uses of the same television program or film are to be divided. Specifically, trade union convergence in this sector would mean bringing together the American Federation of Television and Radio Artists (AFTRA) and the Screen Actors Guild (SAG). But attempts to accomplish this have failed, most recently in 1999 and 2003, in very close votes (McKercher \& Mosco, 2007).

In Canada, attempts to build closer ties among the major telecommunications unions have also not been particularly successful. Setting up the National Association of Communication Unions created formal federation links between the CEP and the Telecommunications Workers Union (TWU). But perhaps because the latter has a history of radicalism (it once took over the telephone exchanges of Vancouver during a strike action in 1981) and because the TWU has eschewed the convergent union idea, the two unions have not worked closely together (Mosco \& McKercher, forthcoming).

Convergence also creates cross-border difficulties, as workers at the CBC experienced when, to facilitate bargaining, the CIRB ordered its unions to merge. Prior to this time, CBC's journalists had been members of the CWA (which won the right of representation when it merged with the Newspaper Guild) and its technicians were part of the CEP. This meant that some employees of Canada's national broadcaster were members of an American union while others were members of a Canadian union. In the ensuing vote, members decided to join the larger CWA, making all employees at Canada's national public broadcaster part of an American union. This form of cross-border convergence has proven to be very useful, contributing significantly to the surprising success of $\mathrm{CBC}$ workers against a management that locked them out in August 2005. This case demonstrated the ability of different types of knowledge worker, in this case journalists and technicians, to work together and maintain solidarity with the help of a strong union, even though that union is based in another country (Mosco \& McKercher, forthcoming).

In 2005, the merger issue heated up in the United States when, in the wake of the big Republican victory in the 2004 general election and the continued decline in union density rates, one of the major unions in the AFL-CIO threatened to pull out unless the federation permitted significant new mergers and other organisational changes. Specifically, the fastest growing major union in the United States, the Service Employees International Union (SEIU), demanded that the federation consolidate several of its member unions and shift funding from its own research and political activity to grassroots organising. Holding out the threat of withdrawal, the SEIU was backed by the powerful Teamsters Union. The AFL-CIO proposed a compromise but was not successful and several unions left the federation to form their own 'Change to Win Coalition' comprising 5.4 million members committed to stepped-up union organising. Partly in response to this major defection, the AFL-CIO set up an industry coordinating committee made up of ten unions covering the arts, entertainment, media and telecommunications industries. The committee's goal is to build labour power in the industries that have been rocked by corporate concentration and technological 
change. Convergence, therefore, may also be a response to the failure of an organisation to maintain its membership.

It is uncertain just how far the urge to merge or the convergence movement will take North American trade unions. Will it bring back the idea of One Big Union, once popular a century ago with the Knights of Labour and Industrial Workers of the World? Can it expand democracy and citizen engagement by empowering a segment of society that has declined over the past three decades? Is it a genuine new start for labour or a last gasp? It is too early to answer these questions. But it is useful to consider different perspectives on the significance of this development.

On the one hand, labour union convergence increases the centralisation of power and bureaucracy, thereby making it less likely that union leadership can maintain close contact with the rank-and-file membership. Indeed the evidence from outside North America is not encouraging. For example, in the 1990s the Australian labour movement succeeded in halving the number of its unions, but this did not stop the erosion of union density. Does trade union convergence mean sacrificing union democracy for various forms of cartel unionism?

On the other hand, convergence does give unions greater clout in collective bargaining, thereby diminishing the power that has been concentrated in big companies over the past three decades. To support this view one can point to the CWA's success in organising wireless telecommunication workers and in defending technical and on-air staff at the CBC. Moreover, mergers allow unions to be more involved in social and political activities. For example, Swift (2003) cites the CEP as an example of a converged communication union that has been more deeply involved in major policy issues since it expanded across the converged information industries, including the struggle to limit media concentration in Canada, as well as the fight against lifting restrictions on foreign ownership of Canadian media. The CEP has been in the forefront of lobbying to maintain public telecommunications in the province of Saskatchewan and public electrical power in Ontario.

Moreover, one of the advantages of a converged union is its ability to rise above the narrow interests of some of its members. So, for instance, even though the CEP represents energy workers, it is fully behind the Kyoto Accords to limit the expansion of greenhouse gasses. Furthermore, it was able to stand up for its paper workers against the powerful wood products company Abitibi because convergence permitted the CEP to draw from the strike funds of its energy and communication industry members. The union also has the resources to create a Quebec Solidarity Fund that permitted it to invest in declining Quebec paper mills and keep them from closing. Furthermore, the CEP has been extensively involved in the anti-globalisation movement and in supporting unionisation in Mexico and throughout Latin America with the help of the CEP Humanity Fund. Converged knowledge worker unions also seem to be able to deliver other benefits for their members. For instance, research conducted by Kiss and Mosco (2005) on what unions are doing about surveillance in the workplace demonstrated that knowledge worker unions, especially convergent unions like the CEP, provide the best protection for workers in their collective agreements. 
Finally, convergence allows unions to work co-operatively as never before. In the United States the AFL-CIO recently threw its support behind a form of convergent unionism in the cultural sector by setting up an industry coordinating committee made up of ten unions covering the arts, entertainment, media and telecommunications industries. The committee's goal is to build labour power in industries that have been shaken by corporate concentration and technological change.

Nevertheless, it is not entirely clear whether converged unions are genuinely bringing together different kinds of workers in the knowledge, information and communication sectors, such as news workers and telephone operators, or merely becoming federations of what are, in effect, dissimilar employees.

\section{Worker associations}

A second response to the crisis in North American organised labour is the formation of worker associations or worker movements that provide benefits to workers without formally negotiating collective agreements. These have been especially prominent in the high-tech sector where union organising has been particularly difficult. They are more evident in the United States than in Canada, though there have been some Canadian initiatives such as the Association des Travailleurs du Multimedia du Quebec, but these have not received substantial support. Worker associations are also more prominent among part-time workers who are difficult to organise by traditional unions because they typically work for an employment agency, not the high-tech company itself. These associations are prominent in California's Silicon Valley where fully $40 \%$ of workers are employed in non-standard ways and in Microsoft's territory in the Pacific Northwest. It was here that the term 'Permatemp' or permanent temporary worker, was coined to describe workers who work full time but on hourly contracts that contain practically no benefits or overtime pay. Among the goals of these associations are the provision of portable benefits for a highly mobile workforce, lifelong training, job placement, assistance to individual workers, dissemination of information to workers and health care plans for workers who are not eligible for employer-paid benefits.

Two types of such associations feature significantly in the knowledge sector, those that represent technology-intensive workers and those that primarily produce content. Perhaps the leading example and model of the former is WashTech, an offshoot of the CWA in the Seattle high-tech industry formed by disgruntled Microsoft permatemps who were successful in a legal action against the company for salary and benefits denied to them because they were placed in the temporary worker category (Brophy, forthcoming; van Jaarsveld, 2004, Rodicino-Colcino, this volume). One of the biggest difficulties workers face in the high tech industry is that many of them do not formally work for the high tech company itself but for companies like Manpower, which provide high tech firms with workers. Nevertheless, what helped forge WashTech was Microsoft's use of its political power to create the 'permatemp' category, thereby denying a large group of otherwise full-time employees the salary and benefits that were available to recognised full-time workers. The lawsuit and the assistance of the CWA helped to galvanise a sufficient number of Microsoft workers to form WashTech.

WashTech includes programmers, editors, web designers, systems analysts, proofers, 
testers and engineers who aim to win higher pay, health benefits, vacation, access to retirement plans, discounted stock options, and workplace training. In addition to taking legal action against Microsoft, WashTech members used their technical skills to unearth a secret Microsoft database on employee performance and distribute it to members. WashTech also found contract documents dating back to 2001 cementing deals to outsource high-end software architecture to Indian firms that the company hoped to keep secret. WashTech has been successful at Microsoft, helped by its association with research advocacy groups such at the Center for a Changing Workforce and its online site Techsunite.org which provides information and online organising for high tech workers. But it has at best enjoyed mixed success in expanding to other knowledge sector workers. It failed to organise disgruntled workers at the online bookseller Amazon.com, but did succeed in organising workers at Cingular wireless. Today, WashTech is especially involved in fighting the outsourcing of tech jobs to places like India and China and has been successful in convincing some state legislators to stop outsourcing government tech work.

Alliance@IBM was also formed by the CWA and, like WashTech, fought to win benefits that were initially denied to workers based on their status in the loosely defined temporary category by their employer, in this case, IBM. The company has been notoriously associated with concerns about toxic chemicals in the workplace and Alliance has been particularly active in fighting occupational safety and health cases before the courts. Alliance has also been successful in winning some formal representation for workers at both Manpower and IBM.

It is unusual to think of engineers as part of the labour movement but the Society of Professional Engineering Employees in Aerospace (SPEEA) has made it necessary for the management at Boeing to do so because in 2000 the Society led the largest white collar strike in US history against the giant manufacturer. Indeed, what makes the SPEEA particularly interesting to those who believe that knowledge work offers the potential for new forms of organising is that much of their success was achieved by the use of email and the Internet. For example, the union managed to collect home email addresses while building a communications network for their strike against Boeing in 2000. In perhaps the most effective use of its database, SPEEA was able to generate a picket line of 500 people in six hours by email alone, to disrupt an unannounced meeting of the Boeing board of directors in a local hotel. There are other noteworthy high tech worker association organising efforts. Systems Administrators Guilds have been set up in the USA (and in the UK and Australia as well) to organise computer workers and intervene in policy debates.

Worker associations are also increasingly prominent among content producers. Working Today is an advocacy group representing independent workers including freelancers, consultants, temps, and contingent workers based in New York in the area known during the high tech boom as Silicon Alley. The group has been particularly successful in providing basic health insurance to members. The Graphic Artists Guild represents web creators, illustrators, and designers who come together to improve working conditions and intervene in processes concerning copyright, taxation and other important policy issues. The Creators' Federation represents freelance writers and 
is credited with winning an important case requiring publishers to receive freelancers' approval before putting their work on a database. Additionally, the National Writers' Union in the United States boasts over 5,000 members for whom it provides model contracts, advice on bargaining with publishers and benefits for people without insurance.

One of the primary reasons for the rise of worker associations in the high tech field is that established trade unions have simply not been successful in their organising drives. Nevertheless, some of the old line unions did meet with some success in the heyday of the dotcom boom when unions like the United Food and Commercial Workers successfully organised dotcom workers involved in the online delivery services of supermarkets like Peabodys and Albrittons. Moreover, the AFL-CIO has been successful in building community affiliates like Working America, combining union and non-union members who pledge to co-operate with unions in political and legislative campaigns. Its founding director is Karen Nussbaum who created the first organisation of women office workers in the 1980s with a group called Nine to Five. The Service Employees International Union has also created an online membership organisation called Purpleocean.org in an effort to expand the union's scope and influence beyond the workplace by engaging in social justice activism.

As with trade union convergence, there is uncertainty over the success of worker associations in responding to the crisis facing organised labour. On the one hand, they provide a new form of unionism that makes use of new technology to reach workers who have little experience with unions. They bring into the labour movement people who do not necessarily want to be part of a trade union and they represent a recognition that formal collective agreements do not mean as much in a world of accelerating mobility. But on the other hand one can also make the argument that these new associations are providing little hope for the future. Since they are, by and large, not directly involved in collective bargaining, worker associations offer few, if any, guarantees for wages and working conditions. Arguably they simply provide evidence of the failure to organise unions in the rapidly growing knowledge sector and, since these jobs embody the workplace of the future, they do not offer much hope for genuine trade unionism. Worker associations may provide a new start toward rebuilding the labour movement, perhaps by reinventing the old guild model, but they may also represent little more than organised labour's last gasp.

\section{Conclusion}

Drawing on documentary evidence and interviews, this paper has examined the response of North American workers in the converging knowledge and communication industries. On the one hand, traditional unions have reacted with their own form of convergence, bringing together workers across the once separate sectors of journalism, broadcasting, telecommunications, information technology and electronic services. Alternatively, other workers in the knowledge industry, including both technical and creative professionals, are experimenting with new forms of worker association that provide benefits for members without necessarily engaging in formal collective bargaining. Our research has provided evidence that these developments have produced 
some genuine achievements but have not yet stemmed the tide of labour's decline in North America.

The next step in our project is to examine the process of labour convergence and worker association formation in the international arena. Specifically, we are about to begin a project that will look at organisations like the International Federation of Journalists, the Union Network International, and workers' associations in India like the IT Professional's Forum, the New Trade Union Initiative, and UNITES (the Union for Information Technology \& Enabled Services Professionals). Developments in the North American labour movement, especially in the knowledge and communication sectors, are no doubt interesting, and potentially significant. But if labour is to respond successfully to the changing international division of labour then it must respond with new forms of convergence at the global level. Examining the state of global labour federations, new worker associations, and their relationships is therefore essential to determine if labour is able to meet the challenges of a global knowledge economy. (c) Vincent Mosco, 2008

\section{REFERENCES}

Artz, L. \& Y.R. Kamalipour (eds.) (2003) The globalisation of corporate media hegemony, Albany: State University of New York Press

Babe, R.E. (1996) 'Convergence and the new technologies', in M. Dorland (ed.), The cultural industries in Canada, Toronto: Lorimer:283-307

Bahr, M. (1998) From the telegraph to the internet, Washington: National Press Books Barley, S.R. \& G. Kunda (2004) Gurus, hired guns, and warm bodies: itinerant experts in a knowledge economy, Princeton: Princeton University Press

Batstone, E. (1984) Working order: workplace industrial relations over two decades, Oxford: Basil Blackwell

Bell, D. (1973) The coming of a post-industrial society, New York: Basic

Bell, D. (1976) The cultural contradictions of capitalism, New York: Basic

Bédard, M. (2005) Union membership in Canada, Ottawa: Human Resources and Skills

Development Canada, Labour Program

Braverman, H. (1973) Labour and monopoly capital, New York: Monthly Review

Brint, S. (2001) 'Professionals and the knowledge economy: rethinking the theory of post-

industrial Society', Current Sociology, Vol 49, No 4:101-132

Brophy, E. (forthcoming) 'System error: Labour precarity and collective organising at Microsoft', Canadian Journal of Communication

Clawson, D. (2003) 'Is Labour on the edge of a new upsurge', Labour Notes, September 2

Dyer-Witheford, N. (1999) Cyber-Marx: cycles and circuits of struggle in high technology capitalism, Chicago: University of Illinois Press

Economic Policy Institute (2004) Offshoring (http://www.epinet.org/content.cfm/issueguide_ offshoring)

Elmer, G. \& M. Gasher (eds.) (2005) Contracting out Hollywood: runaway productions and foreign location shooting, Lanham: Rowman/Littlefield

Herman, E.S. \& N. Chomsky (2002) Manufacturing consent, New York: Pantheon

Huws, U. (2003) The making of a cybertariat: virtual work in a real world, New York: Monthly

Review Press

Karnitschnig, M. (2006) 'Time Warner stops pushing synergy', The Wall Street Journal, June 2. Reprinted in the Pittsburgh Post-Gazette.com, Accessed, June 3, 2006 from: http://www.postgazette.com

Katz, H.C. (ed.) (1997) Telecommunications: restructuring work and employment relations worldwide, Ithaca: ILR Press 
Kiss, S. \& V. Mosco (2005) 'Trade union protection of workers' privacy: A content analysis of English and French-language collective agreements in Canada', Canadian Journal of Communication, Vol 30, No 4:549-564

Kline, S., N. Dyer-Witheford \& G. de Peuter (2003) Digital play: the interaction of technology, culture and marketing, Montreal: McGill-Queen's Press

Longstaff, P.F. (2002) The communication toolkit, Cambridge: MIT Press

Machlup, F. (1962) The production and distribution of knowledge in the United States, Princeton:

Princeton University Press

McKercher, C. (2002) Newsworkers unite: labour, convergence and North American newspapers, Lanham: Rowman and Littlefield

McKercher, C. \& V. Mosco (2007) 'Divided they stand: Hollywood unions in the information age', in Huws, U. (ed) The Spark in the Engine: Creative Workers in a Global Economy, Work, Organisation, Labour and Globalisation, Vol I No 1

Mosco, V. (1996) The political economy of communication, London: Sage

Mosco, V. (2004) The digital sublime: $m y t h$, power, and cyberspace, Cambridge: MIT Press

Mosco, V. (forthcoming, November 2006) 'Knowledge workers in the global economy: Antimonies of outsourcing', Social Identities, Vol 12, No 6

Mosco, V. \& C. McKercher (forthcoming, October 2006) 'Convergence bites back', Canadian Journal of Communication

Negroponte, N. (1996) Being digital, Cambridge: MIT Press

Nichols, J. \& R.W. McChesney (2005) Tragedy and farce: how the American media sell wars, spin elections, and destroy democracy, New York: The New Press

Porat, M.U. (1977) The information economy, Washington, DC: Office of Telecommunications, Department of Commerce

Powell, W. \& K. Snellman (2004) 'The knowledge economy', Annual Review of Sociology, Vol 30:199-220

Schiller, D. (1999) Digital capitalism, Cambridge, MA: MIT Press

Schiller, H.I. (1973) The mind managers, Boston: Beaco .

Statistics Canada (2004) 'Study: the union movement in transition', The Daily, August 31.

Stone, K.V.W. (2004) From widgets to digits: employment regulation for the changing workplace,

Cambridge: Cambridge University Press

Swift, J. (2003) Walking the union walk, Ottawa: Communication Energy and Paperworkers Union of Canada

Terranova, T. (2004) Network culture: politics for the information age, London: Pluto

US Bureau of Labour Statistics (2006) Union members in 2005, Washington, DC: Bureau of Labour Statistics

Van Jaarsveld, D. (2004) 'Collective representation among high-tech workers at Microsoft and beyond: Lessons from WashTech/CWA', Industrial Relations, Vol 43, No 2:364-385

Winseck, D. (1998) Reconvergence: a political economy of telecommunications, Hampton: Hampton Press Winter, J. (2005) Lies the media tell us, Monteal: Black Rose Press

\section{ACKNOWLEDGEMENTS}

This paper was completed with the assistance of a grant from the Social Sciences and Humanities Research Council of Canada to examine Trade Unions and Convergence in the Communications Industry and also with a grant from the Social Sciences and Humanities Research Council which funds The Surveillance Project at Queen's University. I would like to thank the members of numerous unions and worker associations who gave their time for interviews. I would also like to thank my coinvestigator on the Trade Unions project, Professor Catherine McKercher, and research assistants Enda Brophy, Laura Glithero, and Simon Kiss. 